\title{
AKTIVITAS ANTIOKSIDAN DAN KANDUNGAN FENOLIK TOTAL FRAKSI N-HEKSAN DAN KLOROFORM DAUN JERUK PURUT (Citrus hystrix)
}

\section{Fadilah Qonitah, Ahwan}

\author{
Program Studi Farmasi Fakultas Sains Teknologi dan Kesehatan Universitas Sahid Surakarta \\ Email: fadilahqonitah12@gmail.com
}

\begin{abstract}
Free radicals can cause several diseases. Antioxidants are the compounds that can reduce free radicals in the human body. Kaffir lime leaves contain phenolic and flavonoids compounds which have antioxidant activity. This research aimed to evaluate the antioxidant activity and to determine total phenolic contents of fraction n-hexane and chloroform from kaffir lime leaves. The antioxidant activity was determined by radical scavenging assay using DPPH (2,2-diphenyl-1-picrylhydrazyl) radical. The total phenolic content was determined by the spectrophotometric method. The results showed that the antioxidant activity of chloroform fraction (IC50: $302.91 \pm 0.28 \mu \mathrm{g} / \mathrm{mL}$ ) was higher than the $n$-hexane fraction ( $\left(C_{50}: 714,25 \pm 1,97 \mu \mathrm{g} / \mathrm{mL}\right.$ ), but the antioxidant activity was lower than vitamin $C\left(I C_{50}: 3,28 \pm 0,12 \mu \mathrm{g} / \mathrm{mL}\right)$. The total phenolic content of chloroform fraction $(4.73 \pm 0,33 \% \mathrm{~W} / \mathrm{W}$ $E A G)$ was higher than the $n$-hexane fraction $(3,18 \pm 0,31 \% w / w E A G)$.
\end{abstract}

Key words: Antioxidants, total phenolic, kaffir lime leaves.

\section{PENDAHULUAN}

Beberapa penyakit seperti kanker,diabetes melitus, aterosklerosis, penyakit kardiovaskuler, penuaan, dan penyakit peradangan disebabkan oleh stres oksidatif. Stres oksidatif terjadi karena ketidakseimbangan antara radikal bebas dan antioksidan dalam tubuh. Radikal bebas merupakan molekul yang mempunyai elektron tidak berpasangan sehingga tidak stabil. $\mathrm{Di}$ dalam tubuh radikal bebas akan bereaksi dengan makromolekul dalam sel yang sehat sehingga akan menyebabkan kerusakan sel tersebut. ${ }^{1}$

Radikal bebas bersumber dari hasil metabolisme sel normal dalam tubuh atau dapat bersumber dari luar tubuh seperti polusi lingkungan, sinar ultraviolet (UV) dan asap rokok. Reaktifitas dari radikal bebas dapat dihambat oleh antioksidan di dalam tubuh. Antioksidan merupakan senyawa yang dapat menghambat reaksi oksidasi lipid atau molekul lain dengan menghambat inisiasi atau propagasi reaksi oksidasi berantai. Antioksidan yang ada di dalam tubuh jumlahnya terbatas maka dibutuhkan antioksidan eksogen dari luar tubuh. ${ }^{2}$

Antioksidan eksogen terdiri dari antioksidan alami dan antioksidan sintetik. Antioksidan alami dapat diperoleh dari tanaman dan buah-buahan. Senyawa fenolik merupakan senyawa yang mempunyai aktivitas antioksidan yang banyak ditemukan pada tanaman. Banyak penelitian telah melaporkan bahwa ada hubungan antara senyawa fenolik dan polifenol pada tanaman dengan aktivitas antioksidannya. ${ }^{3}$

Salah satu sumber alam yang dapat 
Aktivitas antioksidan dan kandungan fenolik total fraksi n-heksan dan kloroform daun jeruk purut (Citrus hystrix).

dijadikan sebagai antioksidan alami adalah tanaman jeruk purut (Citrus hystrix). Daun jeruk purut mengandung alkaloid polifenol, $\alpha$ tokoferol, minyak atsiri, tannin, steroid triterpenoid, sitronellal, flavanoid sianidin, myricetin, peonidin, quercetin, luteolin, hesperetin, apigenin, dan isorhamnetin. Senyawa-senyawa ini bertindak aktif dalam aktivitas antioksidan terutama senyawa flavonoid. ${ }^{4}$ Berdasarkan data tersebut pada penelitian ini dilakukan untuk mengetahui aktivitas antioksidan dan kandungan fenolik total fraksi n-heksan dan kloroform daun jeruk purut

\section{METODE PENELITIAN}

\section{Pembuatan Fraksi Sampel}

Sebanyak 800 gram simplisia daun jeruk purut yang telah diserbuk, dimaserasi dengan 4 liter etanol 96\%. Didiamkan $3 \times 24$ jam setelah itu disaring dan maserat hasil ekstraksi dievaporasi dengan rotary evaporator pada suhu $60^{\circ} \mathrm{C}$ sampai diperoleh ekstrak kental. Ekstrak etanol daun jeruk yang diperoleh kemudian dipartisis dengan corong pisah menggunakan pelarut $\mathrm{n}$-heksan dan kloroform sehingga diperoleh fraksi $n$-heksan dan fraksi kloroform.

\section{Penentuan Aktivitas Antioksidan Metode DPPH}

Sejumlah larutan sampel dengan berbagai konsentrasi dimasukkan dalam labu takar $5 \mathrm{~mL}$ ditambah dengan $1 \mathrm{~mL}$ DPPH 0,4 $\mathrm{mM}$ dan ditambah etanol sampai batas tanda. Campuran dihomogenkan dan didiamkan selama 30 menit. Setelah itu diukur absorbansinya pada panjang gelombang 517 $\mathrm{nm}$. Sebagai pembanding digunakan vitamin C yang sudah diketahui sebagai antioksidan. ${ }^{5}$ Besarnya persentase aktivitas antioksidan dihitung dengan rumus:

$\%$ inhibisi $=\frac{\text { abs kontrol }- \text { abs sampel }}{\text { abs kontrol }} \times 100 \%$

Nilai $\mathrm{IC}_{50}$ pada penangkapan radikal DPPH diperoleh berdasarkan persamaan regresi linier seri konsentrasi sampel terhadap persen inhibisi, $y=a+b x$. Nilai $I C_{50}$ dapat dihitung dengan menggunakan rumus: $\mathrm{IC}_{50}=\frac{50-a}{b}$

\section{Penentuan Kandungan Fenolik Total}

Sejumlah fraksi uji dimasukkan ke dalam labu takar $5 \mathrm{~mL}$, ditambah dengan 0,2 $\mathrm{mL}$ reagen Folin-Ciocalteu, dan dibiarkan selama 5-8 menit. Campuran selanjutnya ditambah $2 \mathrm{~mL} \mathrm{Na2CO}$ 7\% dan ditambah aquades sampai batas tanda. Setelah itu didiamkan selama 68 menit dan diukur absorbansinya pada panjang gelombang 767 $\mathrm{nm}$. Kandungan fenolik total dinyatakan sebagai gram ekivalen asam galat tiap berat kering subfraksi (\%b/b EAG) ${ }^{6}$

\section{HASIL DAN PEMBAHASAN}

Pada penelitian ini pengukuran aktivitas antioksidan dari fraksi $\mathrm{n}$-heksan dan fraksi kloroform daun jeruk purut dilakukan berdasarkan metode peredaman radikal DPPH yang disajikan pada tabel 1. Dalam metode ini efek peredaman radikal DPPH dihitung berdasarkan persentase pemudaran warna ungu dari DPPH menjadi kekuningan. Besarnya aktivitas antioksidan dinyatakan dalam nilai $\mathrm{IC}_{50}$ yang merupakan besarnya konsentrasi senyawa uji yag dapat meredam radikal DPPH sebesar $50 \%{ }^{7}$

Berdasarkan tabel 1 menunjukkan bahwa fraksi kloroform $\left(\mathrm{IC}_{50}: 302,91 \pm 0,28\right.$ $\mu \mathrm{g} / \mathrm{mL}$ ) mempunyai aktivitas antioksidan lebih besar dibandingan fraksi n-heksan $\left(\mathrm{IC}_{50}\right.$ : $714,25 \pm 1,97 \mu \mathrm{g} / \mathrm{mL}$ ). Semakin kecil nilai $\mathrm{IC}_{50}$ menunjukkan bahwa semakin besar aktivitas antioksidannya. Aktivitas antioksidan dari 
Aktivitas antioksidan dan kandungan fenolik total fraksi $n$-heksan dan kloroform daun jeruk purut (Citrus hystrix).

kedua fraksi tersebut jika dibandingkan dengan vitamin $\mathrm{C}$, aktivitas antioksidanya masih lebih kecil. Hal ini dapat dilihat pada tabel 1 yang menunjukkan bahwa nilai $\mathrm{IC}_{50}$ dari vitamin $C$ sebesar $3,28 \pm 0,12 \mu \mathrm{g} / \mathrm{mL}$.

Tabel 1. Aktivitas antioksidan fraksi $n$-heksan dan fraksi kloroform daun jeruk purut dengan metode $\mathrm{DPPH}$

\begin{tabular}{|c|c|c|c|c|}
\hline \multirow{2}{*}{ Sampel } & \multicolumn{3}{|c|}{$I C_{50}(\mu \mathrm{g} / \mathrm{mL})$} & \multirow{2}{*}{$\begin{array}{c}\text { Rata-rata IC } \\
(\mu \mathrm{g} / \mathrm{mL})\end{array}$} \\
\hline & Replikasi 1 & Replikasi 2 & Replikasi 3 & \\
\hline Fraksi n-heksan & 715,82 & 714,91 & 712,04 & $714,25 \pm 1,97$ \\
\hline Fraksi kloroform & 303,22 & 302,84 & 302,66 & $302,91 \pm 0,28$ \\
\hline Vitamin C & 3,31 & 3,15 & 3,39 & $3,28 \pm 0,12$ \\
\hline
\end{tabular}

Tabel 2. Kandungan fenolik total fraksi n-heksan dan fraksi kloroform daun jeruk purut

\begin{tabular}{ccccc}
\hline \multirow{2}{*}{ Sampel } & \multicolumn{3}{c}{ Kandungan fenolik total (\% EAG) } & \multirow{2}{*}{$\begin{array}{c}\text { Rata-rata kandungan fenolik } \\
\text { total (\%b/b EAG) }\end{array}$} \\
\cline { 2 - 4 } & Replikasi 1 & Replikasi 2 & Replikasi 3 & \\
\hline Fraksi n-heksan & 2,95 & 3,07 & 3,53 & \\
Fraksi kloroform & 4,36 & 4,86 & 4,97 & \\
\hline
\end{tabular}

Berdasarkan penelitian aktivitas antioksidan sering kali dihubungakan dengan senyawa-senyawa fenolik yang dikandung oleh tanaman. Senyawa fenolik dapat meredam senyawa radikal karena mempunyai bersifat sebagai pereduksi, pemberi hydrogen, peredam oksigen singlet dan sebagai pengkelat logam. ${ }^{8}$

Pada penelitian ini pengukuran kandungan fenolik total ditentukan dengan metode spektrofotometri dengan reagen folin Folin-cioucalte menggunakan standar atau baku asam galat. Kandungan fenoli total fraksi n-heksan dan kloroform dan jeruk purut dihitung berdasarkan persamaan kurva baku asam galat dan dinyatakan dalam $\% \mathrm{~b} / \mathrm{b}$ ekivalen asam galat (\% b/b EAG).

Tabel 2 menunjukkan bahwa kandungan fenolik total fraksi kloroform dan fraksi n-heksan masing-masing sebesar 4,73 \pm 0,33 \% b/b EAG dan 3,18 $\pm 0,31 \%$ b/b EAG. Hal ini menunjukkan bahwa kandungan fenolik total fraksi kloroform lebih besar daripada fraksi n-heksan. Data ini dapat mendukung terkait hasil penentuan aktivitas antioksidan yang menujukkan bahwa aktivitas antioksidan fraksi kloroform juga lebih besar dari pada fraksi n-heksan.

\section{KESIMPULAN}

Fraksi kloroform daun jeruk purut mempunyai aktivitas antioksidan lebih besar daripada fraksi $n$-heksan daun jeruk purut dengan nilai $I C_{50}$ sebesar $302,91 \pm 0,28$ $\mu \mathrm{g} / \mathrm{mL}$. Akan tetapi aktivitas antioksidan tersebut lebih kecil dibandingkan vitamin $\mathrm{C}$ dengan nilai $\mathrm{IC}_{50}$ sebesar $3,28 \pm 0,12 \mu \mathrm{g} / \mathrm{mL}$. Fraksi kloroform daun jeruk purut mempunyai mempunyai kandungan fenolik total daripada fraksi n-heksan daun jeruk purut yaitu sebesar $4,73 \pm 0,33 \% \mathrm{~b} / \mathrm{b}$ EAG.

\section{DAFTAR PUSTAKA}

1. Ghosh $S$, Derle $A$, Ahire $M$, More $P$, Jagtap S, Phadatare SD, et al. Phytochemical Analysis and Free Radical Scavenging Activity of Medicinal Plants Gnidia glauca and Dioscorea bulbifera. 2013;8(12):1-18.

2. Sari AK, Ayati R. Penentuan Aktivitas Antioksidan Ekstrak Etanol Daun Jeruk Purut ( Citrus hystrix D . C ) Dengan Metode DPPH ( 1 , 1-diphenyl-2picrylhydrazyl ). 2018;1(2):69-74.

3. Fidrianny I, Johan $\mathrm{Y}$, Sukrasno. Antioxidant Activities Of Different Polarity 
Aktivitas antioksidan dan kandungan fenolik total fraksi n-heksan dan kloroform daun jeruk purut (Citrus hystrix).

Extracts From Three Organs Of Makrut Lime (Citrus hystrix DC) and correlation With Total Flavonoid, Phenolic, Carotenoid Content. Asian J Pharm Clin Res. 2015;8(4):239-43.

4. Rahmi U, Manjang $Y$, Santoni A. Profil Fitokimia Metabolit Sekunder Dan Uji Aktivitas Antioksidan Tanaman Jeruk Purut ( Citrus histrix DC) dan Jeruk Bali ( Citrus maxima ( Burm . f .) Merr ). 2013;2(2303):109-14.

5. Sami FJ, Nur S, Ramli N, Sutrisno B. Uji Aktivitas Antioksidan Daun Kersen (Muntingia calabura L.) Dengan Metode DPPH (1,1-difenil-2-pikrilhidrazil) Dan FRAP (Ferric Reducing Antioxidan
Power). 2006;09(02):683-8.

6. Chun OK, Kim DO, Lee CY. Superoxide Radical Scavenging Activity of the Major Polyphenols in Fresh Plums. J Agric Food Chem. 2003;51(27):8067-72.

7. Karim AA, Azlan A, Ismail A, Hashim $P$, Abd Gani SS, Zainudin $\mathrm{BH}$, et al. and Tyrosinase Inhibitory Activities of Cocoa Pod Extract. BMC Complement Altern Med. 2014;14(381):1-13.

8. Abdul Rohman, Sugeng Riyanto. Aktivitas antioksidan, Kandungan Fenolik Total, Dan Flavonoid Total Daun Mengkudu (Morinda citrifolia L). Agritec, 2007; 27: 147-151. 